\title{
Resistance of quiescent and proliferating airway epithelial cells to $\mathrm{H}_{2} \mathrm{O}_{2}$ challenge
}

\author{
M.P. Smit-de Vries*,\#, M. van der Toorn ${ }^{\#}$, R. Bischoff* and H.F. Kauffman
}

\begin{abstract}
Alveolar epithelial cell injury and recovery are important in the pathogenesis of oxidant-induced lung damage. The alveolar cell line A549 was used to study responses of proliferating and quiescent cells in culture to time- and dose-dependent hydrogen peroxide $\left(\mathrm{H}_{2} \mathrm{O}_{2}\right)$ challenges.

Recovery was monitored after $24 \mathrm{~h}$ of incubation in fresh medium with $10 \%$ serum. The adherent cells were counted and the resistance and recovery of the attached cells was assessed by appearance, by measuring the number of viable, apoptotic and necrotic cells using fluorescentactivated cell sorting, and by determining the intracellular free thiol content.

A549 cells recovered from a 1-h challenge with up to $1 \mathrm{mM} \mathrm{H}_{2} \mathrm{O}_{2}$ but could not sustain a more prolonged challenge $(6$ or $24 \mathrm{~h})$ with $0.5 \mathrm{mM}$ or $1.0 \mathrm{mM} \mathrm{H}_{2} \mathrm{O}_{2}$. These more severe conditions resulted in: loss of cells by detachment from the plate surface; reduced numbers of viable cells primarily due to necrosis; and a strong reduction of the intracellular free thiol content.

Quiescent cells proved to be more sensitive to oxidative stress than proliferating cells. Intracellular free thiol levels apparently play a decisive role in cell survival, preferentially protecting proliferating cells.
\end{abstract}

KEYWORDS: Apoptosis, chronic obstructive pulmonary disease, epithelial cells, necrosis, oxidative stress, thiols

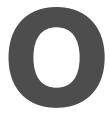
xidative stress is, on a cellular level, a combination of: an increase in reactive oxygen species (ROS) exposure; a decrease in antioxidant protection; and a failure to repair oxidative damage. Oxidative stress and the damage that may result from it have been implicated in a wide number of disease processes, including inflammation, neuronal degeneration and cancer $[1,2]$.

Lungs are exposed to high levels of oxygen and, in the case of smokers, high levels of radicals $\left(10^{14}\right.$ radicals per puff) are inhaled [3]. Chronic obstructive pulmonary disease (COPD), which develops in $20 \%$ of smokers, encompasses both chronic bronchitis and emphysema, currently the fourth leading cause of death in the western world [4]. Emphysema due to oxidative stress and continuous inflammation are major hallmarks of COPD [5]. ROS, either directly from inhaled smoke and/or indirectly from inflammatory cells, may play a role in inflammation $[6,7]$ through the formation of lipid peroxidation products, the activation and phosphorylation of mitogen-activated protein kinases (MAPKs), and through the activation of redox-sensitive transcription factors, such as nuclear factor- $\mathrm{kB}$ and activator protein-1 [8].
Damage by ROS can induce apoptosis (programmed cell death) or necrosis of lung epithelial cells, which is followed by recovery and repair by the proliferation of residual cells [9]. To obtain a detailed description of recovery of cells after an oxidative challenge, the response of the alveolar epithelial cell line A549 to various concentrations of hydrogen peroxide $\left(\mathrm{H}_{2} \mathrm{O}_{2}\right)$ was investigated. The effect of $\mathrm{H}_{2} \mathrm{O}_{2}$ on pulmonary epithelial cells has been studied in earlier investigations using different concentrations and different culture conditions [10-15]. However, the different abilities of proliferating and quiescent lung epithelial cells to recover from various concentrations of $\mathrm{H}_{2} \mathrm{O}_{2}$ have not been studied in a time-dependent manner. A549 is an adenocarcinoma cell line but is related to alveolar epithelial cells, as previous studies show [11, 16], and is known to be sensitive to morphological changes under different stress conditions [17].

Inflamed lung tissue of smokers is exposed to high $\mathrm{H}_{2} \mathrm{O}_{2}$ concentrations. This is reflected in elevated $\mathrm{H}_{2} \mathrm{O}_{2}$ levels in exhaled breath condensate of smokers or patients with exacerbated COPD, compared with ex-smokers or nonsmokers [18]. However, the level of $\mathrm{H}_{2} \mathrm{O}_{2}$ found in healthy or in inflamed lung epithelial cells is

\section{AFFILIATIONS}

*Dept of Analytical Biochemistry, University Centre for Pharmacy, University of Groningen, and ${ }^{*}$ Laboratory for Allergology and Pulmonology, and "Groningen University Institute for Drug Exploration, University Medical Centre Groningen, Groningen, The Netherlands.

\section{CORRESPONDENCE}

H.F. Kauffman

Groningen University Institute for Drug Exploration (GUIDE)

A. Deusinglaan 1

9713 AV Groningen

The Netherlands

Fax: 31503632612

E-mail: Henk.Kauffman@inter.nl.net

Received:

July 172006

Accepted after revision:

December 262006

STATEMENT OF INTEREST

None declared. 
unknown. The current authors hypothesised that resistance and recovery would be dependent not only on the concentration of the oxidative agent but also on the duration of exposure and on the quiescent or proliferating state of airway epithelial cells. To address the hypothesis of the present study, conditions under which A549 cultures were quiescent were established, in order to enable comparisons with proliferating cultures. To define the concentrations of $\mathrm{H}_{2} \mathrm{O}_{2}$ that lead to survival or irreversible damage, and to determine whether these concentrations are different for quiescent versus proliferating cells, the morphology of the adherent cells was assessed, as well as their viability and apoptotic and necrotic status.

Various studies describe $\mathrm{H}_{2} \mathrm{O}_{2}$ as an agent that may indirectly oxidise the free thiol groups of cysteines in peptides and proteins within different types of human cells. In order to sustain their antioxidant defence, cells regenerate the oxidised peptides or proteins via enzymatic reduction and by increasing the expression of antioxidant peptides and proteins. Two major components of thiol-reducing systems, glutathione (GSH) and thioredoxin (TRX), have been identified from various kinds of tissue and appear to dominate the cellular thiol redox potential $[19,20]$. In the present article it is hypothesised that the resistance and recovery of airway epithelial cells to $\mathrm{H}_{2} \mathrm{O}_{2}$ is determined by the pool of reduced thiol components. Therefore, the effect of $\mathrm{H}_{2} \mathrm{O}_{2}$ on the redox state of airway epithelial cells was monitored by measuring the total free thiol content before and after a 24-h recovery period for both proliferating and quiescent cells.

\section{MATERIALS AND METHODS}

\section{Study design}

Basal conditions (no $\mathrm{H}_{2} \mathrm{O}_{2}$ ) were used as controls for the 1, 6 and $24 \mathrm{~h}$ of incubation of quiescent (nondividing) and proliferating cultures with $0,0.1,0.5$ and $1.0 \mathrm{mM} \mathrm{H}_{2} \mathrm{O}_{2}$, followed by a $24-\mathrm{h}$ recovery period (fig. 1a). The parameters that were studied to assess resistance and recovery of A549 cultures were cell morphology, number of adherent cells, cell viability, apoptosis, necrosis and the intracellular free thiol content relative to the protein content (thiol redox state).

\section{A549 epithelial cells}

The human alveolar type II epithelium-like adherent cell line, A549 (ATCC number CCL-185), was maintained in continuous culture, split ratio $1: 5$, at $37^{\circ} \mathrm{C}, 5 \% \mathrm{CO}_{2}$ in RPMI-1640 with L-glutamine (Cambrex, Verviers, Belgium), $20 \mu \mathrm{g} \cdot \mathrm{mL}^{-1}$ gentamicin (Centafarm Services, Etten-Leur, the Netherlands) and $10 \%$ foetal calf serum (FCS; Cambrex). PCR tests for mycoplasma were negative.

\section{Cell proliferation}

Proliferation of A549 cells was measured using a cell proliferation ELISA assay (Amersham, Diegem, Belgium). Briefly, 5,000 cells were cultured in a 96-well microtitre plate at a final volume of $100 \mu \mathrm{L}$ RPMI-1640 supplemented with $10 \%$ FCS and bromodeoxyuridine (BrdU; $10 \mu \mathrm{M}$ ) in each well. After $24 \mathrm{~h}$ the medium was removed. For quiescent cells, the cells were re-incubated overnight in serum-free medium and BrdU. Proliferating cells were maintained in medium with $10 \%$ FCS and BrdU. BrdU incorporation was measured at $450 \mathrm{~nm}$ after $24 \mathrm{~h}$ (both 10\% FCS), $48 \mathrm{~h}$ (with and without 10\% FCS) and

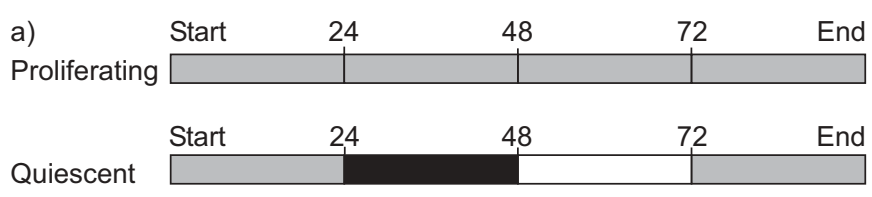

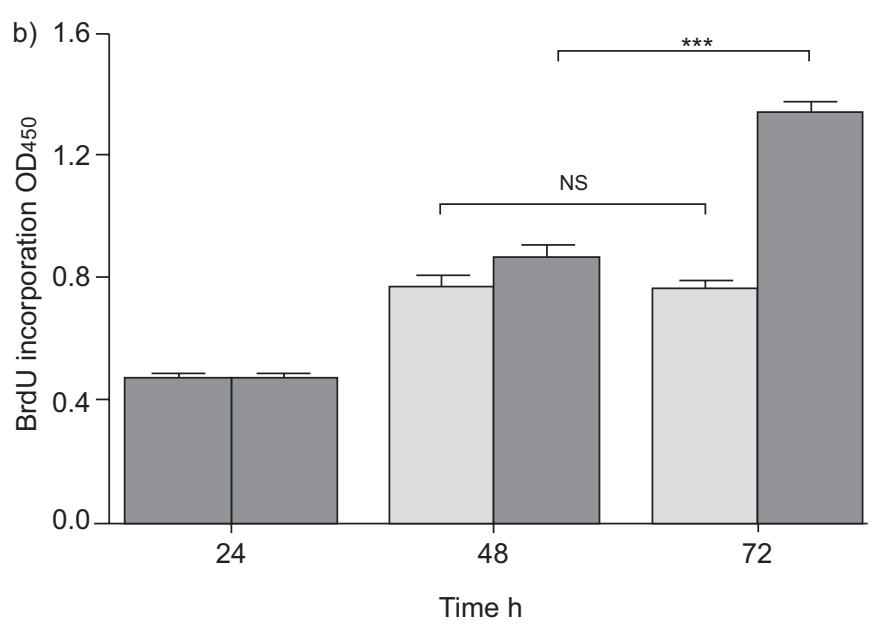

FIGURE 1. a) Experimental design to study the effect of hydrogen peroxide $\left(\mathrm{H}_{2} \mathrm{O}_{2}\right)$ on proliferating and quiescent $\mathrm{A} 549$ cells. After $24 \mathrm{~h}$ of proliferation, the cultures were made quiescent by replacing the medium with serum-free medium and incubating for another $24 \mathrm{~h}$. At time point "48", $\mathrm{H}_{2} \mathrm{O}_{2}(0.1,0.5$ or $1 \mathrm{mM})$ was added to the cultures and the cells were exposed to this oxidative stress for 1, 6 or $24 \mathrm{~h}$. Exposure to $\mathrm{H}_{2} \mathrm{O}_{2}$ was stopped by either harvesting the cells for analysis or by replacing the medium containing $\mathrm{H}_{2} \mathrm{O}_{2}$ with fresh medium supplemented with $10 \%$ foetal calf serum (FCS; exemplified as time point "72"). Cultures were allowed to recover for another $24 \mathrm{~h}$ before analysis ("End"). Proliferating cell cultures were maintained in medium containing 10\% FCS throughout the entire duration of the experiment. Control cultures were treated identically but without $\mathrm{H}_{2} \mathrm{O}_{2}$. $\square$ : medium with $10 \%$ serum; $\mathbf{\square}$ : serum-free medium; $\square$ : incubation with $0.1,0.5$, or $1.0 \mathrm{mM}$ $\mathrm{H}_{2} \mathrm{O}_{2}$ for 1,6 , or 24 h. b) Determination of the quiescent and proliferating state of A549 cell cultures. The increased optical density of a sample, measured at $450 \mathrm{~nm}$ (OD450), correlates directly to the amount of bromodcoxyuridine (BrdU) that has been incorporated into the DNA. After $24 \mathrm{~h}$ in serum-free medium, the cultures were nondividing (quiescent; - ) throughout the duration of the oxidative stress period (until $72 \mathrm{~h}$ ), while the cultures in serum-containing medium continued to proliferate (घ). ${ }^{* \star *}: \mathrm{p}<0.001, \mathrm{n}=4$, paired t-test; NS: nonsignificant.

$72 \mathrm{~h}$ (with and without $10 \%$ FCS), according to the manufacturer's instructions.

\section{Challenge of proliferating or quiescent epithelial cells with $\mathrm{H}_{2} \mathrm{O}_{2}$}

For proliferating cultures, $0.8 \times 10^{5}$ A549 cells $\cdot$ well ${ }^{-1}$ were seeded in sterile 24-well culture dishes (Costar Europe Ltd, Badhoevedorp, the Netherlands) and incubated for $48 \mathrm{~h}$ in the presence of serum. For quiescent cultures, the medium with $10 \%$ FCS was removed after $24 \mathrm{~h}$ of incubation and the cultures were incubated for another $24 \mathrm{~h}$ in serum-free medium. Measures of $0.1,0.5$ and $1 \mathrm{mM} \mathrm{H}_{2} \mathrm{O}_{2}$ (Sigma, St Louis, $\mathrm{MO}$, USA) were added to the cultures and incubated at $37^{\circ} \mathrm{C}$ for 1,6 and $24 \mathrm{~h}$. After incubation, the medium with $\mathrm{H}_{2} \mathrm{O}_{2}$ was removed and the cells were either washed with sterile PBS $\left(\mathrm{Ca}^{2+}\right.$ and $\mathrm{Mg}^{2+}$ free; $\mathrm{pH}$ 7.4) and analysed or washed and 

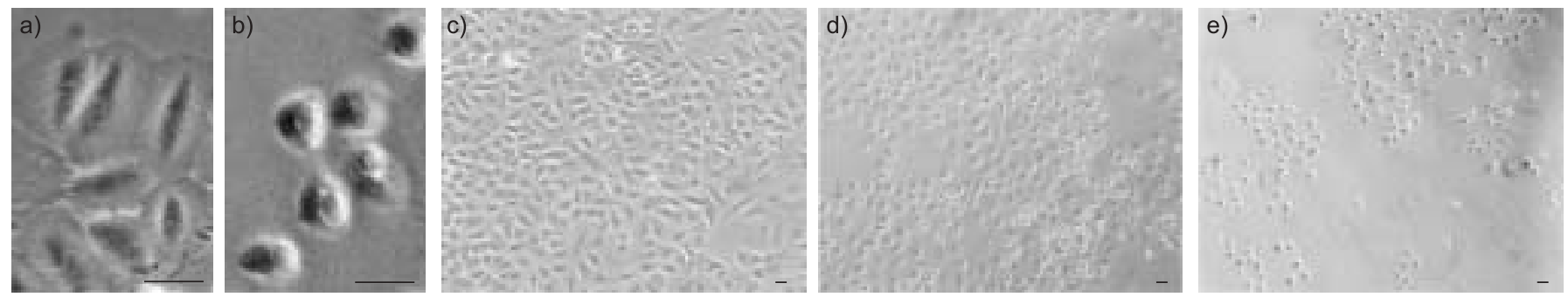

FIGURE 2. Observed morphological changes in A549 cells exposed to $\mathrm{H}_{2} \mathrm{O}_{2}$-mediated oxidative stress. a) Morphology I shows cells that are flat, on average $20 \mu \mathrm{m}$ in size, and have cell-cell contact. b) Morphology II shows rounded cells that have shrunk in size to $\sim 10 \mu \mathrm{m}$ in diameter due to oxidative stress. Most cells have lost contact with neighbouring cells. Basal, unstressed cells are mainly of morphology I but contain $5 \pm 3 \%$ cells of morphology II (c). Both morphologies can occur in a single culture (d), as shown for quiescent cells that were exposed to $0.1 \mathrm{mM} \mathrm{H}_{2} \mathrm{O}_{2}$ for $6 \mathrm{~h}$. Under severe stress situations $\left(24 \mathrm{~h}\right.$ of $0.5 \mathrm{mM} \mathrm{H}_{2} \mathrm{O}_{2}$ ) all remaining cells are of morphology II (e). Scale bars $=10 \mu \mathrm{m}$.

incubated for a further $24 \mathrm{~h}$ in fresh medium with $10 \%$ FCS (recovery phase). The remaining adherent cells were photographed using a Leica phase contrast microscope $(5 \times$; Leica Microsystems $\mathrm{GmbH}$, Wetzlar, Germany) and Leica digital camera (Leica Camera AG, Solms, Germany) to assess the morphology of the cells in the cultures.

\section{Flow cytometry}

After $\mathrm{H}_{2} \mathrm{O}_{2}$ challenge and the subsequent recovery phase, cells were washed and the adherent cells were detached by a 5 -min incubation with $0.05 \%$ trypsin in $0.53 \mathrm{mM}$ ethylenediamine tetraacetic acid (EDTA; GIBCO, Invitrogen Company, Burlington, $\mathrm{ON}$, Canada) at $37^{\circ} \mathrm{C}$, collected, centrifuged ( $300 \times g$ for $\left.5 \mathrm{~min}\right)$ and stained for fluorescent-activated cell sorting (FACS) analysis of apoptosis (annexin V-FITC) and necrosis (propidium iodide (PI)). The Annexin V-FITC/PI Apoptosis/ Necrosis Detection Kit was used according to the manufacturer's instructions (Immune Quality Products (IQP), Groningen, the Netherlands). Cell suspensions were analysed on a FACS Calibur instrument with CellQuest software (Becton Dickinson, Heidelberg, Germany). For each sample, 10,000 events were collected and all analyses of whole cells were performed using appropriate scatter gates to exclude cellular debris and aggregates. Unlabelled cells and labelled basal cultures were used to set the limit of the quadrants; the boundaries of the first quadrant (annexin $\mathrm{V}^{\text {low }}-\mathrm{PI}^{\mathrm{low}}$ ) were set to contain $100 \%$ of an unlabelled cell suspension and $95 \%$ of the labelled cells of basal cultures. These settings were used to analyse all labelled cell suspensions.

\section{Total protein and free thiol measurements}

Cells were washed and lysed by one freeze-thaw cycle in $200 \mu \mathrm{L}$ of demineralised water, and $50 \mu \mathrm{L}$ were used for protein determination by the Bradford assay [21], using a bovine serum albumin (BSA; Sigma) standard curve. The samples were measured at $595 \mathrm{~nm}$ in a Bio-Tek EL808 microplate reader (Beun de Ronde, Abcoude, the Netherlands). $12 \mathrm{mM}$ 5,5'-dithiobis-(2-nitrobenzoic acid) (DTNB; Sigma) in $0.1 \mathrm{mM}$ potassium phosphate buffer ( $\mathrm{pH}$ 7.0; Merck, Haarlem, the Netherlands) was added to the rest of the lysed cells to a final concentration of $6 \mathrm{mM}$ DTNB. After $10 \mathrm{~min}$ the samples were measured at $405 \mathrm{~nm}$ [22]. The amount of free thiols was calibrated against a standard curve of L-cysteine (Sigma).

\section{Direct oxidation of BSA and L-cysteine}

In order to assess the potential for direct oxidation, $250 \mu \mathrm{M}$ BSA in PBS containing $1 \mathrm{mM}$ EDTA, or $250 \mu \mathrm{M}$ L-cysteine in PBS containing $1 \mathrm{mM}$ EDTA, were incubated for $10 \mathrm{~min}$ in the dark with $0,0.1,0.5$ and $1.0 \mathrm{mM} \mathrm{H}_{2} \mathrm{O}_{2}$. Before adding DTNB, the excess $\mathrm{H}_{2} \mathrm{O}_{2}$ was inactivated with catalase. To $100-\mu \mathrm{L}$ aliquots of the reaction, DTNB was added to achieve a final concentration of $6 \mathrm{mM}$, and after a 5-min incubation the thiol content was measured at $405 \mathrm{~nm}$. The amount of free thiols was calibrated against a standard curve of L-cysteine.

\section{Statistical analysis}

The t-test for paired observations was used for comparisons between the basal (nonstressed) values and the values directly after $\mathrm{H}_{2} \mathrm{O}_{2}$ incubation and recovery, and for the comparisons between proliferating and quiescent values. Data are expressed as mean $\pm \mathrm{SEM}$ of four to six determinations per experiment. Each determination corresponded to one generation of A549.

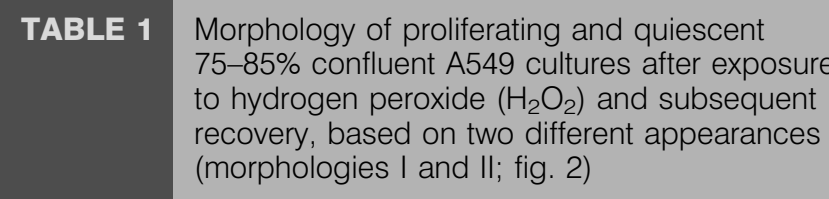

\begin{tabular}{|c|c|c|c|c|c|c|}
\hline \multirow[t]{2}{*}{$\mathrm{H}_{2} \mathrm{O}_{2}$ incubation } & \multicolumn{2}{|c|}{$1 \mathrm{~h}$} & \multicolumn{2}{|c|}{$6 \mathrm{~h}$} & \multicolumn{2}{|c|}{$24 \mathrm{~h}$} \\
\hline & Pro & Qui & Pro & Qui & Pro & Qu \\
\hline Basal morphology no $\mathrm{H}_{2} \mathrm{O}_{2}$ & 1 & 1 & 1 & 1 & 1 & 1 \\
\hline $\begin{array}{l}\text { After } 24 \mathrm{~h} \text { incubation } \mathbf{1 0 \%} \\
\text { serum }\end{array}$ & 1 & I & 1 & I & I & I \\
\hline $0.1 \mathrm{mM} \mathrm{H}_{2} \mathrm{O}_{2}$ after stress & 1 & I & 1 & I, II & 1 & I,II \\
\hline $0.1 \mathrm{mM} \mathrm{H}_{2} \mathrm{O}_{2}$ after recovery & 1 & 1 & 1 & 1 & 1 & I,II \\
\hline $0.5 \mathrm{mM} \mathrm{H}_{2} \mathrm{O}_{2}$ after stress & 1 & I, II & I, II & I, II & $\|$ & $\|$ \\
\hline $0.5 \mathrm{mM} \mathrm{H}_{2} \mathrm{O}_{2}$ after recovery & 1 & 1 & $\|$ & $\|$ & $\|$ & ॥ \\
\hline $1.0 \mathrm{mM} \mathrm{H}_{2} \mathrm{O}_{2}$ after stress & I & I, II & I, II & ॥ & $\|$ & $\|$ \\
\hline $1.0 \mathrm{mM} \mathrm{H}_{2} \mathrm{O}_{2}$ after recovery & 1 & 1 & $\|$ & $\|$ & $\|$ & ॥ \\
\hline
\end{tabular}

Distinct morphologies are: large, flat cells with clear nuclei (I) and small, rounded cells (II). Both morphologies can exist in one culture, which is indicated in this table when one morphology exceeds $15 \%$ of the total cell number. Pro: proliferating cultures; Qui: quiescent cultures. 

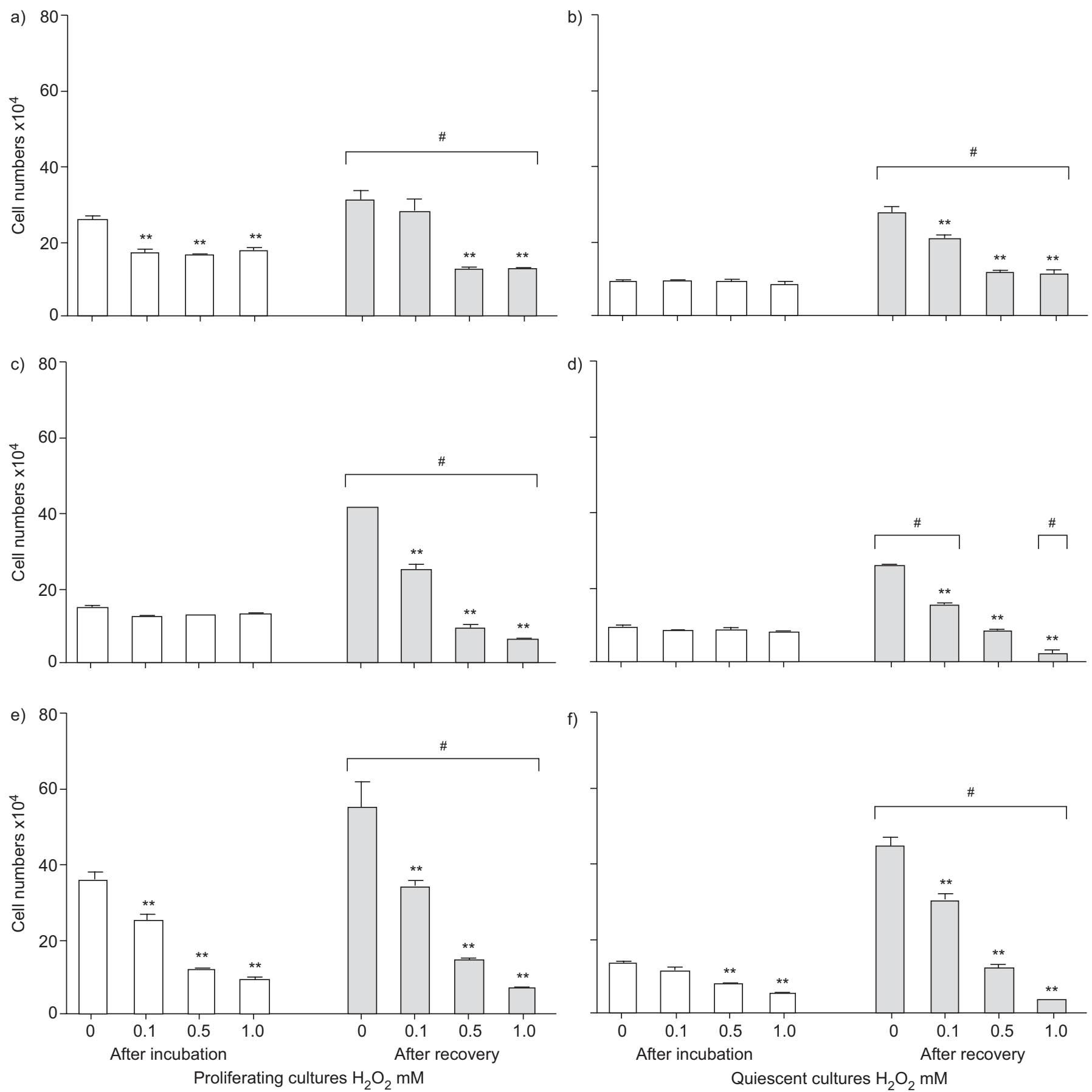

FIGURE 3. Effect of oxidative stress on cell numbers of proliferating and quiescent A549 cultures. Proliferating and quiescent A549 cell cultures were analysed after $1 \mathrm{~h}$ ( $a$ and b), $6 \mathrm{~h}$ ( $\mathrm{c}$ and d) and $24 \mathrm{~h}$ (e and f) of incubation with 0 (basal), 0.1, 0.5 and $1.0 \mathrm{mM}$ hydrogen peroxide $\left(\mathrm{H}_{2} \mathrm{O}_{2} ; \square\right)$ and after $24 \mathrm{~h}$ of recovery in the presence of serumcontaining medium $(\square) .{ }^{*}: p<0.01$ difference of cultures after recovery versus cell numbers directly after incubation, $n=4 ; * *: p<0.01$ difference of stressed samples versus basal cell numbers.

Differences were considered to be statistically significant when $\mathrm{p}<0.01$.

\section{RESULTS}

\section{Proliferation and quiescence}

The schematic outline of the experimental design is depicted in figure 1a. The incorporation of $\mathrm{BrdU}$ was measured to determine the state of quiescence and proliferation. Figure $1 \mathrm{~b}$ shows that in the absence of serum, cultures become quiescent within $24 \mathrm{~h}$ and remain quiescent for $72 \mathrm{~h}$.

\section{Morphological analysis of A549 cells}

The morphology of a cell is defined by its form and appearance, which can change in response to stimuli. Two clearly distinguishable morphologies could be discriminated (fig. 2). Morphology I (MI) relates to cells that are flat with a 

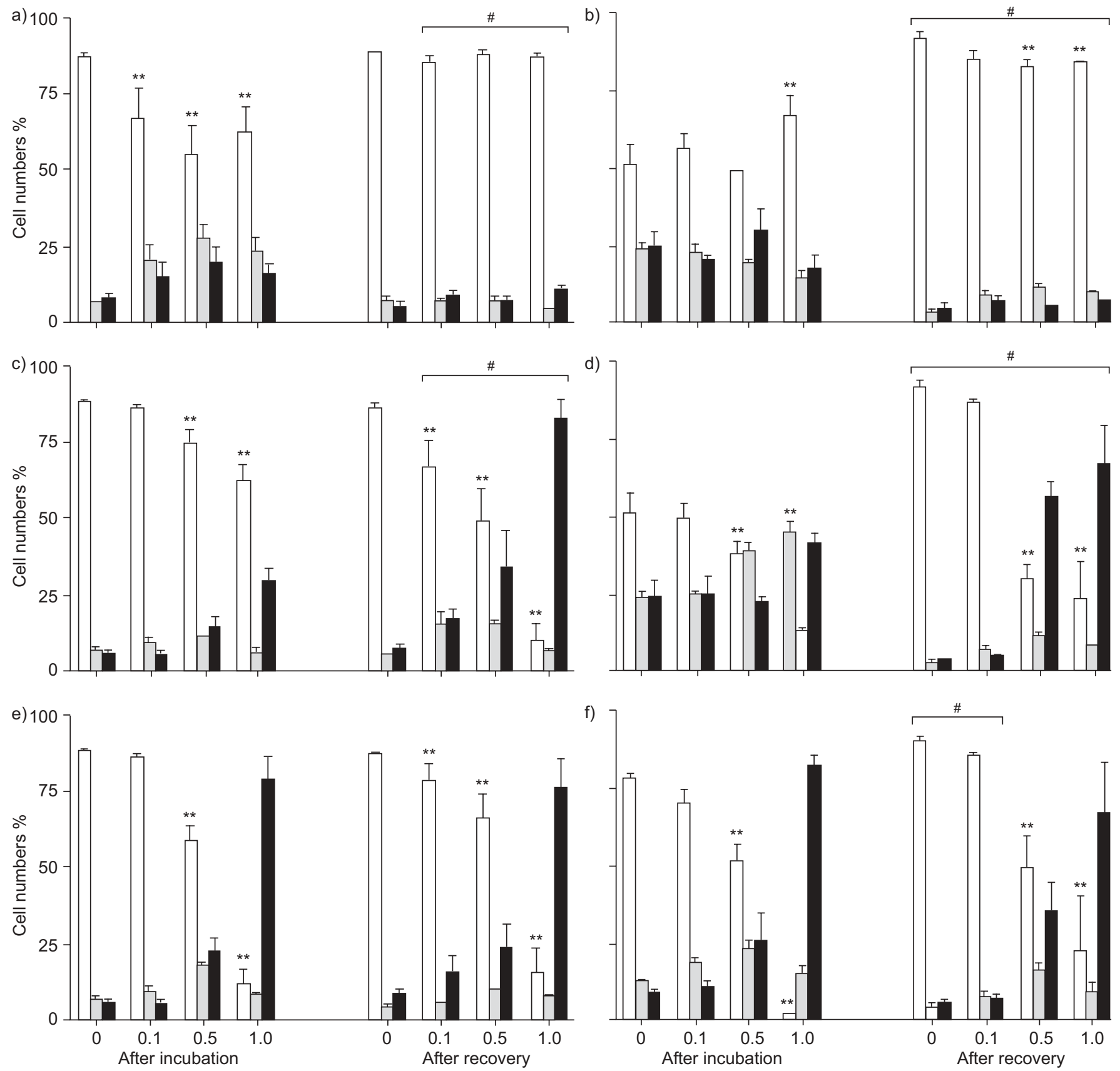

Proliferating cultures $\mathrm{H}_{2} \mathrm{O}_{2} \mathrm{mM}$

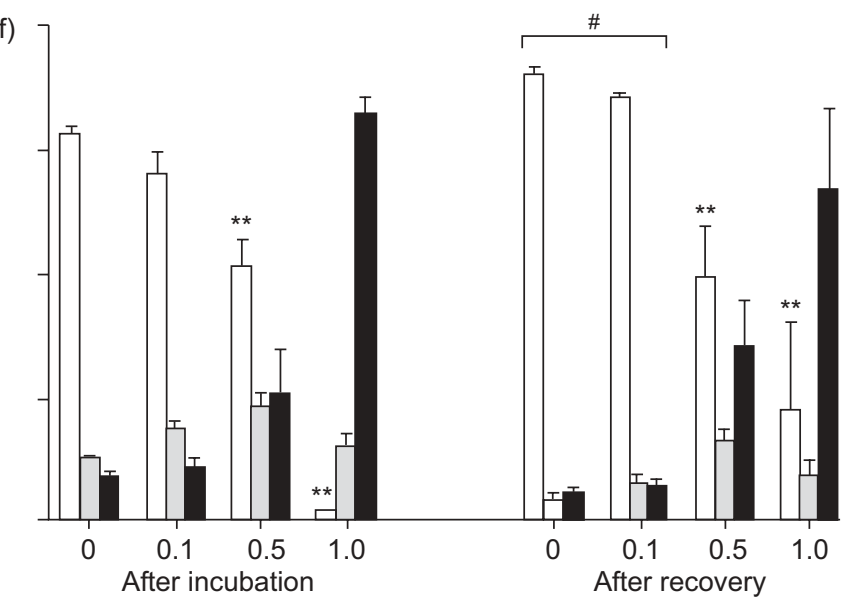

Quiescent cultures $\mathrm{H}_{2} \mathrm{O}_{2} \mathrm{mM}$

FIGURE 4. Percentage of viable, apoptotic and necrotic cells of proliferating and quiescent $A 549$ cultures with hydrogen peroxide $\left(\mathrm{H}_{2} \mathrm{O}_{2}\right)$ at various concentrations for increasing time periods ( $a$ and b, 1 h; c and d, 6 h; e and f, 24 h). Cells with polarised, intact membranes (annexin $V^{\text {low }}$-propidium iodide (PI) ${ }^{\text {low }}$ ) were considered viable ( $\square$ ). Cells with distorted membranes (annexin $V^{\text {high }}$-Pllow) were considered early apoptotic $(\square)$. All cells with damaged membranes (annexin $V^{\text {low }}$-Pl ${ }^{\text {high }}$ and annexin $V^{\text {high }}$-Pl ${ }^{\text {high }}$ ) were considered to be necrotic cells ( $(\mathbf{\square})$. Directly after incubation with $\mathrm{H}_{2} \mathrm{O}_{2}$ or after a 24 -h recovery period, $10^{4}$ cells $\cdot$ culture ${ }^{-1}$ were counted. ${ }^{\#}$ : $p<0.01$ difference of cultures after recovery versus viable cells in cultures directly after incubation, $n=5$; ${ }^{* *}: p<0.01$ difference of viable cells in stressed cultures versus basal viable cultures.

visible nucleus (fig. 2a), where each cell has a diameter of $\sim 20 \mu \mathrm{m}$ and is contacting neighbouring cells. Morphology II (MII) shows rounded cells that have shrunk in size to $\sim 10 \mu \mathrm{m}$ in diameter (fig. 2b), often losing contact with neighbouring cells. In basal cultures at $80 \%$ confluence, $95 \pm 3 \%$ of cells (proliferating and quiescent) show MI (fig. 2c). When cultures contained $>15 \%$ rounded cells (fig. $2 \mathrm{~d}$ ), the designation MII has been added to table 1 , which summarises the status of the cultures under various conditions of oxidative stress. When cultures contained $>85 \%$ rounded cells (fig. $2 \mathrm{e}$ ) the cultures were considered to be entirely MII.

Most cells in the cultures incubated for $1 \mathrm{~h}$ with $0.5 \mathrm{mM}$ and $1.0 \mathrm{mM} \mathrm{H}_{2} \mathrm{O}_{2}$ showed an overall $\mathrm{MI}$ indicative of healthy cells. 


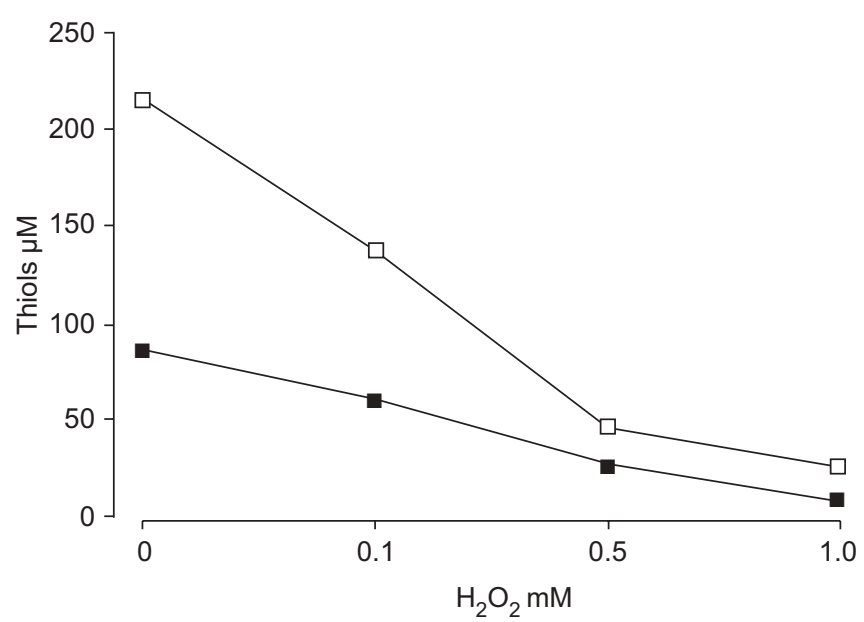

FIGURE 5. Direct oxidation of free thiol groups by hydrogen peroxide $\left(\mathrm{H}_{2} \mathrm{O}_{2}\right)$. The effect of 15-min incubation of $250 \mu \mathrm{M}$ of BSA ( $\mathbf{\square})$ and L-cysteine ( $\square$ ) with increasing concentrations of $\mathrm{H}_{2} \mathrm{O}_{2}$ in the absence of ultraviolet light and in the presence of ethylenediamine tetraacetic acid.

As the time of incubation with 0.5 and $1.0 \mathrm{mM} \mathrm{H}_{2} \mathrm{O}_{2}$ increased from 1 to 6 and 24 hours, the overall culture changed from MI to MII. Once a culture contained $>85 \%$ of MII cells it could not recover in $24 \mathrm{~h}$ to a MI culture. Judging by the number of cells that had changed to MII, quiescent cultures were slightly more sensitive to oxidative stress than proliferating cultures (table 1).

\section{Cell numbers and cell viability}

In MII cultures, a part of the cells became detached from the cell culture dish. The severity of $\mathrm{H}_{2} \mathrm{O}_{2}$ stress was assessed by counting the cells that remained attached to the plate (fig. 3) and analysing their viability by FACS (fig. 4). As a control for the cell counts (and the loss of cells), the total protein content of basal and stressed cultures was measured. The results of the protein assay corresponded to the cell counts (data not shown). FACS analysis showed that the number of viable cells in basal cultures and in the presence of $\mathrm{H}_{2} \mathrm{O}_{2}$ is generally lower in quiescent than in proliferating cultures.

After $1 \mathrm{~h}$ of stress, the proliferating cultures showed a decrease of cell numbers as compared with the unstressed cultures, along with an increase in apoptotic and necrotic cells. The quiescent cultures did not show this dose response after $1 \mathrm{~h}$ and contained even more viable cells after $1 \mathrm{~h}$ of $1.0 \mathrm{mM} \mathrm{H}_{2} \mathrm{O}_{2}$ challenge than the basal cultures. After $6 \mathrm{~h}$ of stress the cultures did not show a dose response, as the number of cells remained constant, but the number of necrotic cells increased with increasing $\mathrm{H}_{2} \mathrm{O}_{2}$ concentration. This was more profound for quiescent cultures. During the 24-h stress period a decrease of cell numbers corresponding to increasing $\mathrm{H}_{2} \mathrm{O}_{2}$ concentrations was observed, which was stronger for proliferating cultures than quiescent cultures. However, the residual adherent proliferating cells were more resilient to the challenge with $1.0 \mathrm{mM} \mathrm{H}_{2} \mathrm{O}_{2}$, as reflected by the higher number of viable cells than in quiescent cultures.

After the recovery period, the basal cultures obviously had increased cell numbers. It was observed that epithelial cells recovered from exposure to increasing $\mathrm{H}_{2} \mathrm{O}_{2}$ concentrations after $1 \mathrm{~h}$ of incubation, as was shown by the increased viability of the remaining adherent cells. Similarly, epithelial cells recovered from $0.1 \mathrm{mM} \mathrm{H} \mathrm{H}_{2} \mathrm{O}_{2}$ independent of exposure time. However, cell numbers did not reach the "recovered" unstressed culture values (except for the 1-h incubation of proliferating cells).

During the recovery period after $6 \mathrm{~h}$ of stress, the cell numbers had decreased, as reflected by an increase of mainly necrotic cells. This increase in necrotic cells was more profound for quiescent cultures, especially after recovery from $0.5 \mathrm{mM}$ $\mathrm{H}_{2} \mathrm{O}_{2}$. After recovery from $24 \mathrm{~h}$ of stress, the cell numbers had increased slightly after $0.5 \mathrm{mM} \mathrm{H}_{2} \mathrm{O}_{2}$ and had decreased slightly after $1.0 \mathrm{mM} \mathrm{H}_{2} \mathrm{O}_{2}$.

The difference between proliferating and quiescent cultures becomes clear when analysing cell viability. The relative number of viable and necrotic cells did not change in proliferating cultures during the recovery period. However, in quiescent cultures after recovery from $1.0 \mathrm{mM} \mathrm{H}_{2} \mathrm{O}_{2}$ the remaining adherent cells were significantly more viable than directly after the stress.

\section{Oxidation of free (cellular) thiol groups}

$\mathrm{H}_{2} \mathrm{O}_{2}$ is considered to be a precursor for radicals generated by mitochondrial metabolism. However, incubation of $\mathrm{H}_{2} \mathrm{O}_{2}$ in the presence of the metal chelator EDTA, and in the absence of light, showed a rapid oxidation of cysteines (fig. 5).

The ratio between oxidised and reduced thiol groups can be considered to be an indicator of oxidation. Since free thiol groups play an important role in the defence against oxidative stress, the effect of $\mathrm{H}_{2} \mathrm{O}_{2}$ on the total cellular level of free thiols was measured relative to the protein content (fig. 6). Cellular oxidative stress by $\mathrm{H}_{2} \mathrm{O}_{2}$ was reflected in a lower free thiol/ protein ratio of most cultures, compared with basal unstressed values. First of all it was observed that basal quiescent cultures had a higher thiol/protein ratio than proliferating basal cultures. However, the free thiol/protein ratio in quiescent cultures had diminished more strongly compared with the basal values, especially after $24 \mathrm{~h}$ of stress, in contrast to the proliferating cultures.

After the recovery period, the quiescent cultures had returned to a proliferating state and subsequently showed lower free thiol/protein ratios. Based on these changed basal values, the quiescent cultures subjected to $0.1 \mathrm{mM} \mathrm{H}_{2} \mathrm{O}_{2}$ had recovered. At higher stress levels $(0.5$ and $1.0 \mathrm{mM})$, recovery of the thiol to protein ratio was still observed after $1 \mathrm{~h}$ of stress and, remarkably, even after $24 \mathrm{~h}$ of $0.5 \mathrm{mM} \mathrm{H}_{2} \mathrm{O}_{2}$.

After the recovery period of proliferating cultures, it was observed that the cultures recovered from all $\mathrm{H}_{2} \mathrm{O}_{2}$ concentrations for $1 \mathrm{~h}$ of stress and from $0.1 \mathrm{mM} \mathrm{H}_{2} \mathrm{O}_{2}$ for 6 and $24 \mathrm{~h}$. Remarkably, proliferating cultures showed a high free thiol/ protein ratio after recovery from 6 and $24 \mathrm{~h}$ of $0.5 \mathrm{mM} \mathrm{H}_{2} \mathrm{O}_{2}$. Another remarkable result was the presence of free thiols after recovery from $24 \mathrm{~h}$ of $1.0 \mathrm{mM} \mathrm{H}_{2} \mathrm{O}_{2}$ in proliferating cultures, whereas in quiescent cultures these values had diminished to zero. This indicates that some of the remaining attached cells of MII morphology (mainly necrotic cells), had responded to the challenge by strongly increasing their thiol redox balance. By 

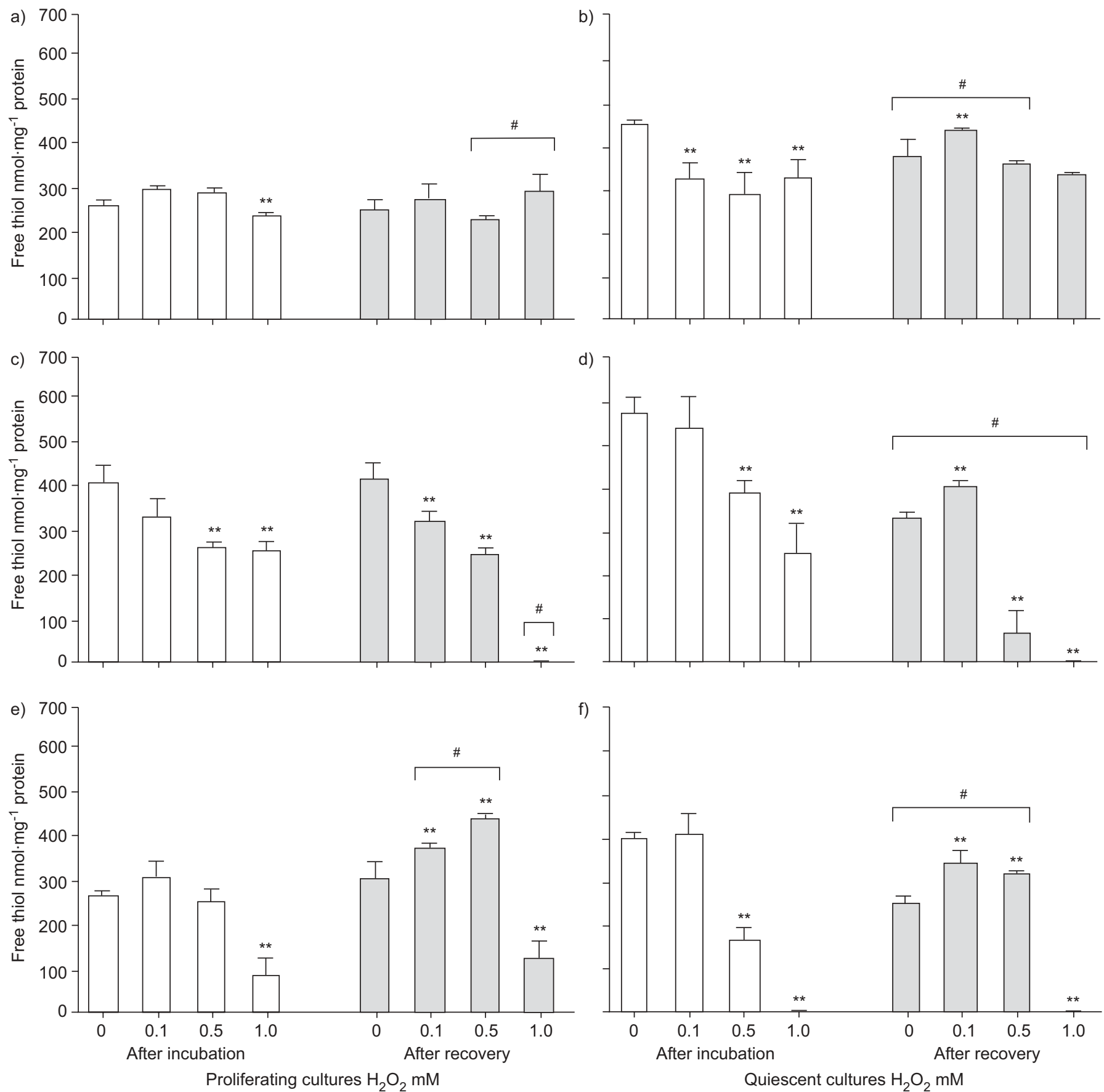

FIGURE 6. Oxidation of free thiols expressed as thiol/protein ratio $\left(\mathrm{nmol} \cdot \mathrm{mg}^{-1}\right)$ in $\mathrm{A} 549$ cells after exposure to hydrogen peroxide $\left(\mathrm{H}_{2} \mathrm{O}_{2}\right)$ at various concentrations for increasing time periods. Proliferating and quiescent cell cultures were incubated with $0,0.1,0.5$ and $1.0 \mathrm{mM} \mathrm{H}_{2} \mathrm{O}_{2}$ for $1 \mathrm{~h}(\mathrm{a}$ and b), $6 \mathrm{~h}(\mathrm{c}$ and d) and $24 \mathrm{~h}(\mathrm{e}$ and f). The free thiol redox balance was calculated directly after challenge $(\square)$ and after recovery $(\square) .{ }^{*}: p<0.01$ difference of cultures after recovery versus the thiol redox balance directly after incubation, $n=4 ;{ }^{*}: p<0.01$ difference of stressed cultures versus the basal cultures.

measuring the total GSH content (GSH and disulfide-bound GSH (GSSG)), similar results were obtained (data not shown).

Cells entering necrosis have a low free thiol/protein ratio. Figure 7 relates the average thiol concentration in nmoles $\cdot \mathrm{mL}$ to the percentage of necrotic cells. As the morphology is a visual indication of the stress level, figure 7 also includes the different morphologies. In general, a trend was observed that cultures with a low thiol concentration contained the most MII cells and necrotic cells.

\section{DISCUSSION}

$\mathrm{H}_{2} \mathrm{O}_{2}$ is one of the oxidants formed through oxygen metabolism and during inflammation as part of the oxidative burst. In studies on A549 and other cells, widely different conditions for 

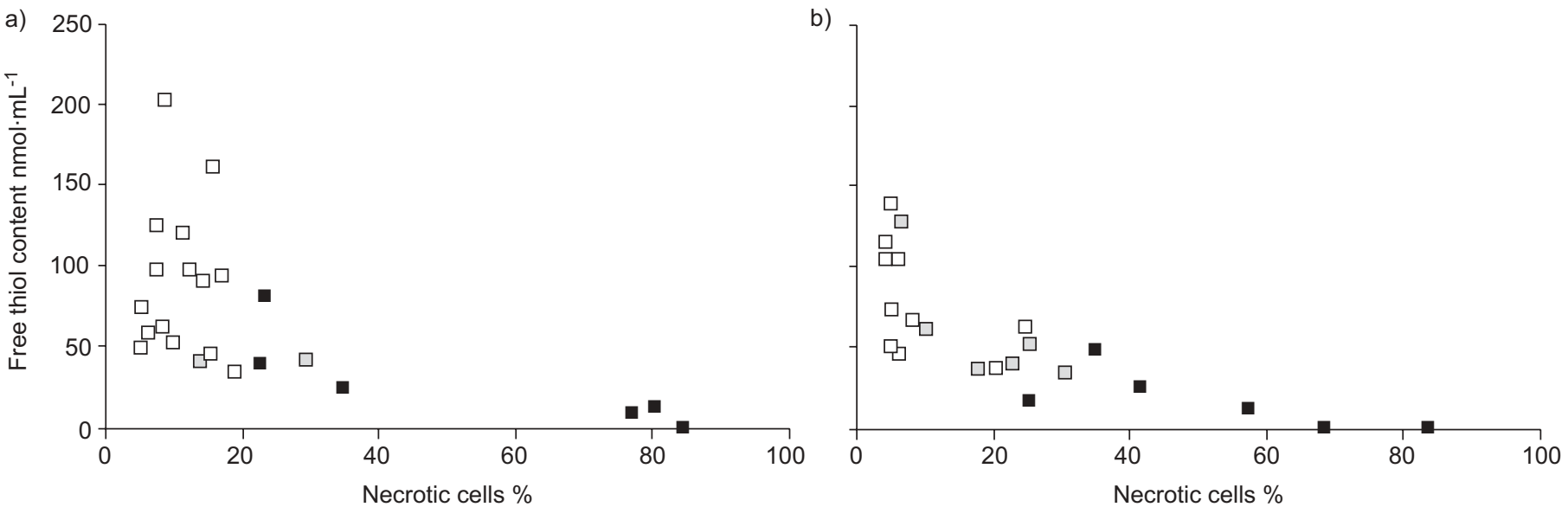

FIGURE 7. Correlation between the number of necrotic cells and the thiol content of A549 cultures. a) Proliferating and b) quiescent cultures were analysed for free thiol content and percentage of necrotic cells after hydrogen peroxide $\left(\mathrm{H}_{2} \mathrm{O}_{2}\right)$ administration and after a recovery period. All cells with damaged membranes (annexin $V^{\text {low }}$ propidium iodide $(\mathrm{PI})^{\text {high }}$ and annexin $\mathrm{V}^{\text {high }}$ P $^{\mathrm{P}^{\text {high }}}$ ) were considered to be necrotic cells. The morphology of the cells in proliferating and quiescent cultures is shown:

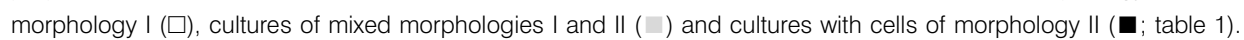

$\mathrm{H}_{2} \mathrm{O}_{2}$ incubations have been used [10-13, 15]; this prompted the current authors to perform a detailed time-dependent dose-response study and to define limits for in vitro resistance and recovery. For this purpose, cells were challenged with $\mathrm{H}_{2} \mathrm{O}_{2}$ at concentrations above levels implicated in cell signalling $(50 \mu \mathrm{M})$ [23] but below levels that would lead to cell death within minutes $(10 \mathrm{mM})$. In most described cases, A549 cells are maintained in medium containing serum up to the moment the experiment starts $[11,12,15]$. When the cultures are not $100 \%$ confluent it is likely that they are still proliferating at the start of the experiment.

In the present report it has been demonstrated that differences in cell viability and the relative content of free thiols of basal quiescent and proliferating cultures influence their ability to recover from oxidative stress. FACS analysis (fig. 4) showed that a higher percentage of cells are viable in basal proliferating cultures compared to quiescent cultures. This indicates that cells are in a more viable state when they are growing in a medium containing $10 \%$ serum.

In contrast, basal quiescent cultures maintained a higher protein/thiol ratio (fig. 6). These basal quiescent cultures showed a remarkable decrease in free thiols after the addition of serum, indicating that in general the thiol redox balance of proliferating cells is lower. It is important to note that the observations argue against a simple correlation between the free thiol/protein ratio and antioxidant defence during stressfree conditions. Quiescent cells have a higher thiol redox balance than proliferating cells but are nevertheless more sensitive to oxidative stress. Differences are most prominent after 6- and 24-h exposures, especially to $0.5 \mathrm{mM} \mathrm{H}_{2} \mathrm{O}_{2}$ and subsequent recovery, where it was observed that quiescent cultures are more vulnerable (figs 3, 4 and 6).

When the proliferating and quiescent cultures were stressed with $\mathrm{H}_{2} \mathrm{O}_{2}$ and subsequently incubated for recovery, morphological differences and changes in cell numbers were observed. These differences prompted the current authors to investigate whether they could be related to a different physiology of quiescent cultures opposed to proliferating cultures. Furthermore, a causal relation was found between cell morphology, free thiol content and the number of necrotic cells for proliferating cultures, and it was also found that this correlation was less strong for quiescent cultures (fig. 7). These differences were not influenced by the thiol content of the external medium. The thiol content of the medium was measured prior to the addition of $\mathrm{H}_{2} \mathrm{O}_{2}$ and it was found that the thiol content was not significantly different in the medium of proliferating cultures compared with that of quiescent cultures (data not shown).

The present data help define a threshold of $\mathrm{H}_{2} \mathrm{O}_{2}$ stress up to which A549 cells can recover when supplemented with serumcontaining medium. All cultures could recover from shortterm $(1 \mathrm{~h})$ exposure to $0.1-1.0 \mathrm{mM} \mathrm{H}_{2} \mathrm{O}_{2}$, or from long-term exposure (up to $24 \mathrm{~h}$ ) to low $\mathrm{H}_{2} \mathrm{O}_{2} \quad(0.1 \mathrm{mM})$ concentrations. However, cells underwent irreversible changes after incubation times longer than $1 \mathrm{~h}$ with higher $\mathrm{H}_{2} \mathrm{O}_{2}$ concentrations $(0.5-1.0 \mathrm{mM})$, as indicated by a modified morphology (cell shrinkage), decreased cell viability and an increased number of cells detaching from the plate surface. This is consistent with previous findings in the literature [14]. This recovery from oxidative stress may mimic, to some extent, the situation in vivo, where epithelial cells may be exposed to oxidative stress followed by a recovery period (e.g. after a smoking episode).

It is of interest to study how both quiescent and proliferating epithelial cells cope with oxidative stress, as there are indications that cells start to proliferate upon lung damage. When the lungs are damaged, both quiescent and proliferating cells are likely to respond differently to oxidative stress. It has been reviewed that upon tissue damage, growth factors are responsible for proliferation and remodelling of airway epithelium to repair the damage in COPD [24]. However, reliable data on the in vivo rate of proliferation in the human 
lung is not available. An indication of the proliferation rate is derived from literature on pulmonary gene therapy studies in mouse lungs, where 28 days after transient transfection with an adenoviral vector the expressed transfected gene product had disappeared [25]. In current experiments described in the literature, it is not always clear whether the cells were incubated with or without serum previous to the experiment.

In vitro quiescent cultures form a homogenous population of cells in the same state, facilitating analysis. Mammalian cells deprived of serum stop proliferating and become arrested, usually between mitosis and S-phase, in a specialised, nonproliferating G0 state, called quiescence. It is known that the cellular redox potential varies during the lifespan of a cell. For example, the cellular redox state has characteristic set points depending on whether cells are quiescent, proliferating, differentiating or apoptotic [26, 27]. The current authors hypothesise that these differences explain in part the sensitivity of quiescent cultures to oxidative stress. The proliferating cultures are heterogeneous, as cells are in different phases of mitosis, all responding more or less strongly to oxidative stress. However, the cells in the homogenous quiescent cultures will all respond similarly, marking the sensitivity and the lack of recovery of the cultures after $6 \mathrm{~h}$ of $0.5 \mathrm{mM}$ $\mathrm{H}_{2} \mathrm{O}_{2}$.

The lung epithelium in vivo is constantly exposed to high concentrations of oxygen and other oxidants from endogenous and exogenous sources, especially during smoking [28]. ROS causes cellular injury via reactions leading to more reactive species, such as hydroxyl radicals and lipid peroxidation products. A source of ROS is $\mathrm{H}_{2} \mathrm{O}_{2}$, which is known to cause oxidative stress through depletion of free thiols. $\mathrm{H}_{2} \mathrm{O}_{2}$ is directly generated during cigarette smoking ( 22-37 $\mu \mathrm{g} \mathrm{H}_{2} \mathrm{O}_{2}$ per aqueous tar extract from one cigarette) [29]. Additionally, $\mathrm{H}_{2} \mathrm{O}_{2}$ is produced within epithelial cells as a result of mitochondrial metabolism, reduced nicotinamide adenine dinucleotide phosphate oxidase [14], glycollate and monoamine oxidase activity [23], and by superoxide dismutase in the cytoplasm. In this report it has been shown that $\mathrm{H}_{2} \mathrm{O}_{2}$ is able to directly oxidise free thiols without the need for cellular metabolism as exemplified by the in vitro oxidation of BSA and L-cysteine (fig. 5).

In studies conducted by the current authors, A549 cells went into a state of necrosis without any pronounced signs of apoptosis, which led to a study of the activation state of caspase-3, a cysteine proteinase, during a selected number of experimental conditions. Interestingly, there was no indication of caspase- 3 activation at 0.5 or $1 \mathrm{mM} \mathrm{H}_{2} \mathrm{O}_{2}$ after long-term incubation, as studied by Western blotting (data provided by D.J. Slebos (Groningen, the Netherlands), not shown), which may explain the lack of apoptosis. Although not proven, it is likely that the active site cysteine in caspase- 3 was directly oxidised by $\mathrm{H}_{2} \mathrm{O}_{2}$ or its metabolites, thus inactivating the enzyme [30,31]. This is in line with results reported here that $\mathrm{H}_{2} \mathrm{O}_{2}$ can directly oxidise free thiol groups, e.g. in BSA and cysteine.

\section{Conclusion}

Quiescent cultures appear to be more sensitive than proliferating cultures, especially to prolonged incubations with higher
$\mathrm{H}_{2} \mathrm{O}_{2}$ concentrations. The aim of the present study was to define the upper concentration limit of $\mathrm{H}_{2} \mathrm{O}_{2}$ from which quiescent and proliferating cells can recover when returned to serum-containing medium, for the purpose of future studies on the analysis of proteins involved in the recovery process. This upper concentration limit appears to be $0.1 \mathrm{mM} \mathrm{H}_{2} \mathrm{O}_{2}$, as all cultures were able to recover from this concentration. Another important factor is the time of exposure, as incubations with 0.5 and $1.0 \mathrm{mM} \mathrm{H}_{2} \mathrm{O}_{2}$ for $>1 \mathrm{~h}$ resulted in loss of attached cells and an increase in necrotic cells. In proliferating cultures there are a limited number of cells remaining viable after severe oxidative stress, and it appears that they have adapted to this condition by increasing their thiol/protein ratio considerably after recovery.

Many regulatory proteins contain critical cysteine residues that are sensitive to: oxidation to sulfenic acids; the formation of intra- and intermolecular disulfides; or mixed disulfides with glutathione [32]. In general, free (reduced) thiol groups play an important role in the defence against oxidative stress and healthy cells are generally found in a reduced state, having a large excess of reduced compared with oxidised thiols. The maintenance of this state is critical and is dependent on the equilibrium between oxidised and reduced thiols. The current authors are studying how the free thiols in proteins of cultures react to these borderline conditions of oxidative stress, in order to elucidate protective mechanisms that aid stress resistance and to correlate this to recovery or cell death. These studies may elucidate the inter-individual differences in susceptibility to oxidation-mediated tissue damage and inflammation, as is observed in the $20 \%$ of smokers that develop chronic obstructive pulmonary disease, whereas the remaining $80 \%$ do not show pulmonary limitations.

\section{ACKNOWLEDGEMENTS}

The authors appreciate the work done by D.J. Slebos (Groningen, the Netherlands), the excellent technical assistance of H.G. de Bruin (Groningen, the Netherlands) and the financial support of the Jan Kornelis de Cock Foundation (Groningen, the Netherlands).

\section{REFERENCES}

1 Floyd RA. Role of oxygen free radicals in carcinogenesis and brain ischemia. FASEB J 1990; 4: 2587-2597.

2 Finkel T. Oxidant signals and oxidative stress. Curr Opin Cell Biol 2003; 15: 247-254.

3 Pryor WA. Cigarette smoke radicals and the role of free radicals in chemical carcinogenicity. Environ Health Perspect 1997; 105: Suppl. 4, 875-882.

4 Viegi G, Scognamiglio A, Baldacci S, Pistelli F, Carrozzi L. Epidemiology of chronic obstructive pulmonary disease (COPD). Respiration 2001; 68: 4-19.

5 Rutgers SR, Postma DS, ten Hacken NH, et al. Ongoing airway inflammation in patients with COPD who do not currently smoke. Thorax 2000; 55: 12-18.

6 Maestrelli P, Saetta M, Mapp CE, Fabbri LM. Remodeling in response to infection and injury. Airway inflammation and hypersecretion of mucus in smoking subjects with chronic obstructive pulmonary disease. Am J Respir Crit Care Med 2001; 164: S76-S80. 
7 Boots AW, Haenen GRMM, Bast A. Oxidant metabolism in chronic obstructive pulmonary disease. Eur Respir J 2003; 22: Suppl. 46, 14s-27s.

8 Rahman I. Oxidative stress in pathogenesis of chronic obstructive pulmonary disease: cellular and molecular mechanisms. Cell Biochem Biophys 2005; 43: 167-188.

9 Rutgers SR, Timens W, Kauffman HF, Postma DS. Markers of active airway inflammation and remodelling in chronic obstructive pulmonary disease. Clin Exp Allergy 2001; 31: 193-205.

10 Rahman I, Li XY, Donaldson K, Harrison DJ, MacNee W. Glutathione homeostasis in alveolar epithelial cells in vitro and lung in vivo under oxidative stress. Am J Physiol 1995; 269: L285-L292.

11 Anseth JW, Goffin AJ, Fuller GG, Ghio AJ, Kao PN, Upadhyay D. Lung surfactant gelation induced by epithelial cells exposed to air pollution or oxidative stress. Am J Respir Cell Mol Biol 2005; 33: 161-168.

12 Rahman I, Mulier B, Gilmour PS, et al. Oxidant-mediated lung epithelial cell tolerance: the role of intracellular glutathione and nuclear factor-кB. Biochem Pharmacol 2001; 62: 787-794.

13 Rahman I, Gilmour PS, Jimenez LA, MacNee W. Oxidative stress and TNF- $\alpha$ induce histone acetylation and NF- $\kappa \mathrm{B} /$ AP-1 activation in alveolar epithelial cells: potential mechanism in gene transcription in lung inflammation. Mol Cell Biochem 2002; 234-235: 239-248.

14 Dandrea T, Hellmold H, Jonsson C, et al. The transcriptosomal response of human A549 lung cells to a hydrogen peroxide-generating system: relationship to DNA damage, cell cycle arrest, and caspase activation. Free Radic Biol Med 2004; 36: 881-896.

15 Lehtonen ST, Markkanen PMH, Peltoniemi M, Kang SW, Kinnula VL. Variable overoxidation of peroxiredoxins in human lung cells in severe oxidative stress. Am J Physiol Lung Cell Mol Physiol 2005; 288: L997-L1001.

16 Lannan S, Donaldson K, Brown D, MacNee W. Effect of cigarette smoke and its condensates on alveolar epithelial cell injury in vitro. Am J Physiol 1994; 266: L92-L100.

17 Kauffman HF, Tomee JF, van de Riet MA, Timmerman AJ, Borger P. Protease-dependent activation of epithelial cells by fungal allergens leads to morphologic changes and cytokine production. J Allergy Clin Immunol 2000; 105: 1185-1193.

18 Dekhuijzen PN, Aben KK, Dekker I, et al. Increased exhalation of hydrogen peroxide in patients with stable and unstable chronic obstructive pulmonary disease. Am J Respir Crit Care Med 1996; 154: 813-816.
19 Arner ES, Holmgren A. Physiological functions of thioredoxin and thioredoxin reductase. Eur J Biochem 2000; 267: 6102-6109.

20 Rahman I, MacNee W. Lung glutathione and oxidative stress: implications in cigarette smoke-induced airway disease. Am J Physiol 1999; 277: L1067-L1088.

21 Bradford MM. A rapid and sensitive method for the quantitation of microgram quantities of protein utilizing the principle of protein-dye binding. Anal Biochem 1976; 72 : 248-254.

22 Deakin H, Ord MG, Stocken LA. 'Glucose 6-phosphatedehydrogenase' activity and thiol content of thymus nuclei from control and X-irradiated rats. Biochem J 1963; 89: 296-304.

23 Halliwell B, Clement MV, Long LH. Hydrogen peroxide in the human body. FEBS Lett 2000; 486: 10-13.

24 Chung KF. Cytokines in chronic obstructive pulmonary disease. Eur Respir J 2001; 18: Suppl. 34, 50s-59s.

25 Koehler DR, Sajjan U, Chow YH, et al. Protection of Cftr knockout mice from acute lung infection by a helperdependent adenoviral vector expressing Cftr in airway epithelia. Proc Natl Acad Sci USA 2003; 100: 15364-15369.

26 Shackelford RE, Kaufmann WK, Paules RS. Oxidative stress and cell cycle checkpoint function. Free Radic Biol Med 2000; 28: 1387-1404.

27 Schafer FQ, Buettner GR. Redox environment of the cell as viewed through the redox state of the glutathione disulfide/glutathione couple. Free Radic Biol Med 2001; 30: 1191-1212.

28 Cross CE, van der Vliet A, O’Neill CA, Louie S, Halliwell B. Oxidants, antioxidants, and respiratory tract lining fluids. Environ Health Perspect 1994; 102: Suppl. 10, 185-191.

29 Yan F, Williams S, Griffin GD, et al. Near-real-time determination of hydrogen peroxide generated from cigarette smoke. J Environ Monit 2005; 7: 681-687.

30 Hampton MB, Stamenkovic I, Winterbourn CC. Interaction with substrate sensitises caspase-3 to inactivation by hydrogen peroxide. FEBS Lett 2002; 517: 229-232.

31 Baker A, Santos BD, Powis G. Redox control of caspase-3 activity by thioredoxin and other reduced proteins. Biochem Biophys Res Commun 2000; 268: 78-81.

32 Fratelli M, Demol H, Puype M, et al. Identification by redox proteomics of glutathionylated proteins in oxidatively stressed human T lymphocytes. Proc Natl Acad Sci USA 2002; 99: 3505-3510. 